\title{
sciendo
}

\section{MENTAL HEALTH AND QUALITY OF LIFE OF FRONTLINE HEALTH CARE WORKERS AFTER ONE YEAR OF COVID-19 PANDEMIC}

\author{
ABDULBARI BENER ${ }^{1}$, DINESH BHUGRA ${ }^{2}$, ANTONIO VENTRIGLIO ${ }^{3}$

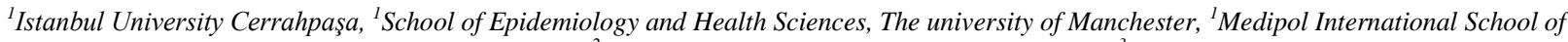 \\ Medicine, Istanbul Medipol University, ${ }^{2}$ Institute of Psychiatry, King 's College London, ${ }^{3}$ University of Foggia, Italy
}

\begin{abstract}
Keywords: $\quad$ COVID-19 pandemic; public health, depression, anxiety, stress, fear, burnout

Abstract: Aim: This study aimed to investigate the impact of more than one year of COVID-19 pandemic on the quality of life and mental health (in terms of depression, anxiety, stress, fear, burnout - workload) among Frontline Health Care Workers (HCWs). Subjects and methods: This is a crosssectional survey based on 1,479 frontline HCW participants aged 20-65 years in Turkey who completed a survey including the 21-item Depression, Anxiety, Stress Scale (DASS-21), Burnout, Fear of COVID19 Scale (FCV-19S), and WHO (World Health Organization) Quality of Life instruments during March-July 2021. Bivariate, factorial and multivariate statistical analyses were performed. Results: Statistically significant differences were found between three frontline groups of HCWs (Physicians, Nurses, Others) including: age ( $p<0.001)$, gender ( $p<0.001)$, educational level $(p<0.001)$, income $(p<0.001)$, number of calls per week ( $p<0.001)$. There were significantly high scores of fear of COVID19 for all items among physicians. The findings also showed that the prevalence of depression $(p=0.002)$, anxiety $(p<0.001)$, and stress $(p<10.005)$ and Pittsburgh Sleep Quality Index $(p=0.011)$ were significantly different among the three groups of frontline HCWs. The work-related burnout was over $30 \%$ in general. The Kaiser-Meyer-Olkin Measure was 0.840 and indicated that the data of the study were suitable for a factor analysis. The factor analysis found out three factors with eigenvalue greater than one. These factors were consistent with the original scale. The multiple linear regression analysis revealed anxiety ( $p<0.001)$, stress( $p<0.001)$, fear of COVID-19 and Burnout $(p=0.008)$, depression $(p=0.004)$, lack of sleeping- Pittsburgh Sleep Quality Index $(p=0.014)$ and feeling exhausted $(p=0.025)$ were associated with the quality of life during the COVID-19 pandemic after adjusting for the age and gender. Conclusion: The findings of this study show that fear and burnout related to COVID-19 were significantly associated with high scores of depression, anxiety, stress, and burnout after one year of pandemic among frontline-HCWs, with poor quality of life and sleep.
\end{abstract}

\section{INTRODUCTION}

The world is currently struggling with one of the biggest pandemic of human history. Unfortunately, the coronavirus disease 2019 (COVID-19), first identified on December 31, 2019 in Wuhan, China, has been spreading all over the world as a global challenge with significant mortality and morbidity according to the World Health Organization report.(1) Also, the COVID-19 pandemic has been associated with relevant mental health issues including depression, anxiety, stress disorders and fear in the general population as well as professional health care workers (HCWs).(2-9) Due to high levels of stress and fear related to COVID-19, individuals might not think clearly.(10) Specifically, Ahorsu et al. (11) developed a valid and reliable scale to assess and detect the fear of COVID-19.

The professional HCWs have provided a very wide spectrum of services during the COVID-19 pandemic. In Turkey, as in the rest of world, they have been working very hard in all health services. $(10,12,13)$ It has been described that fear may be triggered by many factors including the rise of infected cases, confinement at home, poor health facilities, lack of psychiatric services, and poor health information. $(10,12,14)$ Several studies have confirmed that mental health issues have rapidly increased after the outbreak of the pandemic. $(2,9,15-16)$ A recent study conducted in Italy reported that anxiety, depression, stress, and other mental health diseases increased particularly during the first wave of lockdown.(13) Many reports have confirmed that the COVID-19 pandemic is associated with higher distress, anxiety, anger, stress, and agitation in the general population. $(2,4,9,13,15-17)$

We assumed that medical professionals, especially those exposed to COVID-19 at work, would have higher levels of depression, anxiety, stress, fear and burnout after over one year of pandemic. Thus, this study aimed to investigate the impact of COVID-19 on mental health and quality of life in terms of depression, anxiety, stress, fear, burnout - workload among Frontline Health Care Workers (HCWs).

\section{MATERIALS AND METHODS}

\section{Participants and procedure}

The study was conducted in Istanbul, which is a metropolitan city located between Europe and Asia. The study design was cross-sectional and multicentric based on survey involving people living in the urban and rural areas of Istanbul. The sample size calculation was based on the following

${ }^{1}$ Corresponding author: Abdulbari Bener, Göztepe Mahallesi, Atatürk Caddesi, No. 40, 34815, Beykoz- İstanbul, Turkey, E-mail: abdulbari.bener@medipol.edu.tr, Phone: +90535 6639090

Article received on 03.08.2021 and accepted for publication on 02.09.2021 


\section{PUBLIC HEALTH AND MANAGEMENT}

parameters: Sample size formula (Sample Size $\mathrm{n}=\mathrm{N} *\left[\mathrm{Z}^{2} * \mathrm{p} *\right.$ $\left.(1-\mathrm{p}) / \mathrm{e}^{2}\right] /\left[\mathrm{N}-1+\left(\mathrm{Z}^{2} * \mathrm{p} *(1-\mathrm{p}) / \mathrm{e}^{2}\right]\right)$ and calculation is based on the following parameters: margin error $=2.7 \%, Z=$ confidence level $=99 \%, Z \alpha /_{2}=2.58$ for a $99 \%$ confidence interval and prevalence rate $50 \%$ from previous similar studies on health care workers from China.(17) Finally, computed sample size needed to be 2,044 subjects, a multi-stage a total of 2,044 persons were approached during March to July 2021, and $1,479(72.3 \%)$ participants completed the questionnaire. Multistage cluster sampling method performed and KaiserMeyer-Olkin Measure of Sampling Adequacy was 0.852 . the survey:

The following rating scales have been included in

Depression Anxiety Stress Scale (DASS-21):

The 21-item DASS-21 was used to assess depression, anxiety, and stress $(18,19)$ with three subscales (depression, anxiety, stress) including seven items. Each item is scored on a four-points scale ranging from 0 to 3 . The total score is calculated by summing the scores of each subscale and multiplying by two. In the present study the reliability coefficients of the subscales were all valid for depression $(\alpha=0.858)$, anxiety $(\alpha=0.808)$ and stress $(\alpha=0.785)$. Cronbach alpha internal consistency coefficient for the whole scale was computed as $\alpha=0.82$. Recommended cut-off scores for the DASS-21 were used to categorize the participants as follows: depression was categorized as normal (0-9), mild (10-20), and severe $(\geq 21)$; anxiety was categorized as normal (0-7), mild (8$14)$, and severe $(\geq 15)$, and stress was categorized as normal (0$14)$, mild (15-25), and severe ( $\geq 26$ ).

The Fear of COVID-19 Scale:

The seven-items unidimensional FCV-19S (11) was used to assess the fear of COVID-19. Each item is based on a five-points Likert scale ranging from 1 (strongly disagree) to 5 (strongly agree) with a scoring range of 7 to 35 . It was developed by Ahorsu et al. (11), and adapted into Turkish language by Satıc1 et al.(20) The higher the score, the greater the fear of COVID-19. In the present study the Cronbach's alpha for FCV-19S was $\alpha=0.74$.

\section{Burnout scale:}

Burnout is described as a state of physical, emotional, and mental exhaustion of long-term involvement in work. A questionnaire-based survey included the Maslach Burnout Inventory (MBI) (21) and Copenhagen Burnout Inventory (CBI) (22) was carried out among HCWs. The domain based on the work-related burnout (perceived to be related to person's work) had six items. The second domain on the Pandemic-related burnout had six items, with higher the score suggesting higher level of burnout. In this study, the Cronbach's alpha coefficient was found as 0.90 for work related Burnout, and 0.89 for pandemic related Burnout.

The World Health Organization Quality of Life Assessment (WHOQOL-BREF):

WHOQOL-BREF scale contains a total of 26 items: items 3-26 represent four domains ("Physical Health"-7 items; "Psychological Health"-6 items; "Social Relationships"-3 items; "Environment"-8 items (WHOQOL-BREF (23) and by Skevington et al.(24) The answers for each item are given on a 1-5 Likert-type scale, where 1 denotes the least, and 5 is the highest agreement with a particular claim. Items 3,4 , and 26 are negatively phrased and reversed during the analysis. The Cronbach's alpha values, as a measure of the internal consistency of the domains, were satisfactory and the value for the overall scale structure was 0.86 .

Pittsburgh Sleep Quality Index (PSQI)

Buysse et al. (25) developed the PSQI to describe subjective sleep disturbance over the past month. Participants were classified as "Good sleep quality" for the total score of
PSQI $\leq 5$, "Average sleep quality" for the total score of PSQI between 6 and 8 , and "Poor sleep quality" for the total score of PSQI $\geq 9$. In the analysis of internal consistency, the Cronbach's alpha reliability coefficient for the Turkish PSQI was 0.88 , demonstrating high reliability.

The ethical approval obtained from the Istanbul Medipol University, Faculty of Medicine, from the Clinical Research Ethics Committee of Istanbul Medipol University, Institutional Review Board (Research Protocol and IRB\# 10840098604.01.01-E.14180 and IRB\# E-10840098-772.02-65154).

\section{Statistical analysis}

The Statistical analysis of the study was performed using the Statistical Package for the Social Sciences v. 24.0 software package (SPSS - IBM Corporation, New York, NY, USA). The present study distribution was determined by Shapiro-Wilk and Kolmogorov-Smirnov tests. Significant differences between the means of continuous variables were calculated using student's $t$-tests. Chi-square tests were used to determine significant differences between two or more categorical variables. One way analysis of variance (ANOVA) was employed for comparison of several group means Principal Component Analysis (PCA) with Varimax rotation and Kaiser Normalization were performed to examine the factor structure of the DASS21 in the HCWs sample. Multivariate stepwise linear regression analysis was used to determine the association between the burnout and DASS-21. A level of $p<0.05$ was used as cut-off value for statistical significance.

\section{RESULTS}

Table no. 1 presents the comparison of sociodemographic characteristics of the frontline HCWs by occupational status. Statistically ssignificant differences were obtained between three frontline groups of HCWs-including: age $(p<0.001)$, gender $(p<0.001)$, educational level $(p<0.001)$, income $(p<0.001)$, number of calls per week $(p<0.001)$.

Table no. 1. Socio-demographic characteristics of the frontline HCWs surveyed by Gender $(N=1,479)$

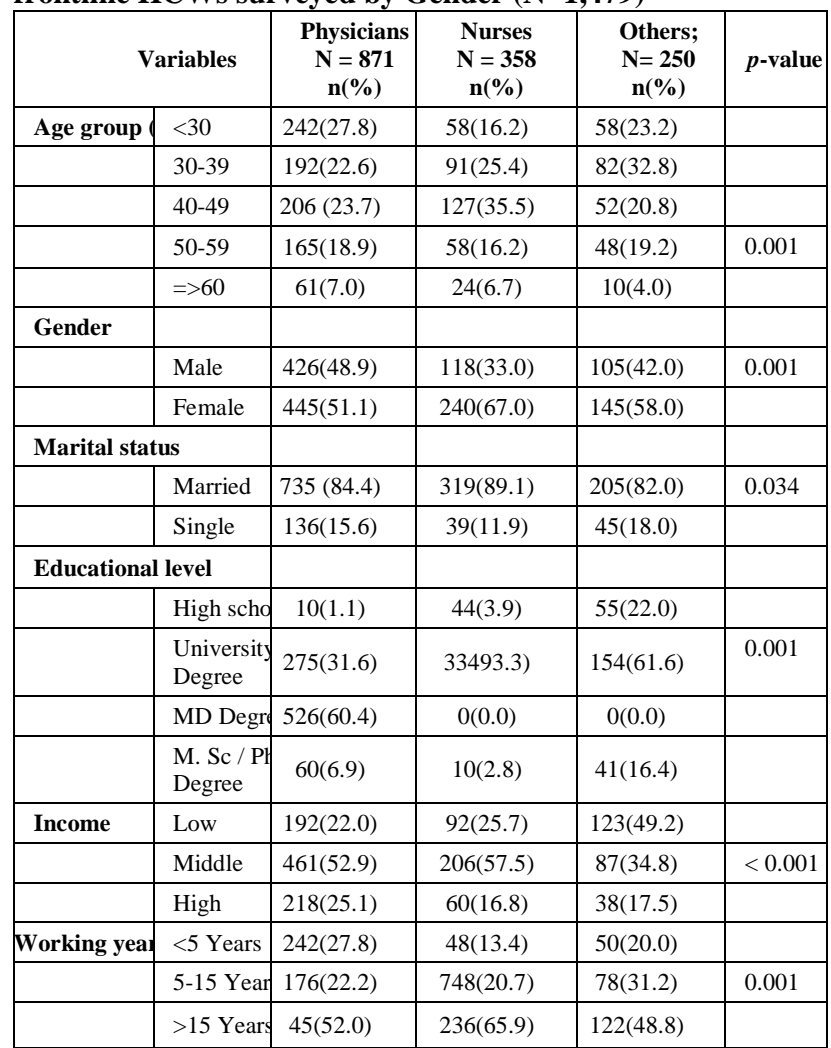




\section{PUBLIC HEALTH AND MANAGEMENT}

\begin{tabular}{|l|l|l|l|l|l|}
\hline Number of & $=<3$ roon & $638(73.4)$ & $255(71.2)$ & $189(75.6)$ & 0.481 \\
\hline & $>3$ room & $231(26.6)$ & $103(28.8)$ & $61(24.4)$ & \\
\hline $\begin{array}{l}\text { No. Family } \\
\text { member }\end{array}$ & $=<5$ peop & $482(60.9)$ & $205(71.2)$ & $147(58.8)$ & 0.579 \\
\hline & $>5$ peop & $389(49.1)$ & $153(42.7$ & $103(41.2)$ & \\
\hline $\begin{array}{l}\text { No. Calls pe } \\
\text { week }\end{array}$ & $=<2$ calls & $645(79.0)$ & $314(87.7)$ & $226(90.4)$ & 0.001 \\
\hline & $>2$ calls & $226(26.0)$ & $44(12.3)$ & $24(96)$ & \\
\hline Smoking & Yes & $170(19.5)$ & $74(20.7)$ & $57(22.8$ & 0.517 \\
\hline & No & $701(80.5)$ & $284(79.3)$ & $193(77.2)$ & \\
\hline
\end{tabular}

Table no. 2 presents the descriptive analysis of the FCV-19S with means, standard deviations of each item by the frontline $\mathrm{HCW}$. There were significantly higher scores among frontline physicians' participants with a history of fear of COVID-19 for all items.

Table no. 2. The Turkish fear scale FCV-19S among studied Frontline HCW $(\mathrm{N}=\mathbf{1 , 4 7 9}$

\begin{tabular}{|c|c|c|c|c|}
\hline Items & $\begin{array}{c}\text { Physicians } \\
\text { N }=871 \\
\text { Mean } \pm \\
\text { SD }\end{array}$ & $\begin{array}{c}\text { Nurses } \\
\mathrm{N}=358 \\
\text { Mean } \pm \\
\text { SD }\end{array}$ & $\begin{array}{c}\text { Others } \\
\mathrm{N}=250 \\
\text { Mean } \pm \text { SD }\end{array}$ & Pvalue \\
\hline $\begin{array}{l}\text { 1. I am most } \\
\text { afraid of COVID- } \\
19 \text {. }\end{array}$ & $2.71 \pm 1.28$ & $3.01 \pm 1.25$ & $3.13 \pm 1.33$ & 0.001 \\
\hline $\begin{array}{l}\text { 2. It makes me } \\
\text { uncomfortable to } \\
\text { think about } \\
\text { COVID-19. }\end{array}$ & $2.91 \pm 1.36$ & $2.85 \pm 1.32$ & $3.09 \pm 1.32$ & 0.098 \\
\hline $\begin{array}{l}\text { 3. My hands } \\
\text { become clammy } \\
\text { due to COVID- } 19 \text {. }\end{array}$ & $3.00 \pm 1.28$ & $2.61 \pm 1.59$ & $2.70 \pm 1.59$ & 0.040 \\
\hline $\begin{array}{l}\text { 4. I am afraid of } \\
\text { losing my life } \\
\text { because of } \\
\text { COVID- } 19 \text {. }\end{array}$ & $3.25 \pm 1.46$ & $3.22 \pm 1.49$ & $3.18 \pm 1.38$ & 0.806 \\
\hline $\begin{array}{l}\text { 5. When watching } \\
\text { news about } \\
\text { COVID-19, I } \\
\text { become nervous. }\end{array}$ & $3.21 \pm 1.49$ & $3.31 \pm 1.44$ & $3.02 \pm 1.45$ & 0.061 \\
\hline $\begin{array}{l}6 . \text { I cannot sleep } \\
\text { because worry } \\
\text { about getting } \\
\text { COVID-19. }\end{array}$ & $3.03 \pm 1.52$ & $3.05 \pm 1.46$ & $2.90 \pm 1.157$ & 0.443 \\
\hline $\begin{array}{l}\text { 7. My heart races } \\
\text { /palpitates when } \\
\text { think about getting } \\
\text { COVID-19. }\end{array}$ & $3.07 \pm 1.49$ & $3.37 \pm 1.40$ & $3.08 \pm 1.50$ & 0.003 \\
\hline
\end{tabular}

Table no. 3 shows the prevalence of depression, anxiety, stress symptoms, and sleeping disorder among Frontline HCWs by occupational status. The findings showed that the prevalence of depression ( $\mathrm{p}=0.002)$, anxiety $(\mathrm{p}<0.001)$, and stress $(p<0.001)$ and PSQI $(p=0.011)$ were statistically significantly differences among the three groups of frontline HCW.

Table no. 4 shows work-related burnout the mean scores of work-related burnout and distribution of responses among frontline HCWs by physicians, nurses and other professionals There were higher statistically significant differences between the three groups of frontline physicians, nurses and other HCWs for all item regarding the COVID-19 burnout scores.

Table no. 3. Prevalence of depression, anxiety and stress symptoms in Frontline HCWs $(N=1,479)$

\begin{tabular}{|l|c|c|c|l|}
\hline & $\begin{array}{c}\text { Physician's N } \\
\mathbf{8 7 1} \\
\mathbf{n ( \% )}\end{array}$ & $\begin{array}{c}\text { Nurses } \mathbf{N}= \\
\mathbf{3 5 8} \\
\mathbf{n}(\boldsymbol{\%})\end{array}$ & $\begin{array}{c}\text { Other } \mathbf{N}= \\
\mathbf{2 5 0} \\
\mathbf{n ( \% )}\end{array}$ & p value \\
\hline Depression & & & & \\
\hline Normal (0-9) & $163(18.7)$ & $84(23.5)$ & $69(27.6)$ & \\
\hline
\end{tabular}

\begin{tabular}{|l|c|c|c|r|}
\hline Mild (10-13 & $182(20.9)$ & $90(25.1)$ & $61(24.4)$ & \\
\hline Moderate (14-20 & $172(19.7)$ & $78(21.8)$ & 3614.4 & 0.00 \\
\hline Severe (21-27) & $238(27.3)$ & $76(21.2)$ & $55(22.0)$ & \\
\hline Very severe >28 & $116(13.3)$ & $30(8.4)$ & $29(11.6)$ & \\
\hline Anxiety & & & & \\
\hline Normal (0-7) & $261(30.0)$ & $\begin{array}{c}105 \\
(29.3)\end{array}$ & $84(33.6)$ & \\
\hline Mild (8-9) & $198(22.7)$ & $\begin{array}{c}123 \\
(34.4)\end{array}$ & $70(28.0)$ & \\
\hline Moderate (10-14) & $138(15.8)$ & $53(14.8)$ & $40(16.0)$ & 0.00 \\
\hline Severe (15-19) & $141(16.2)$ & $45(12.6)$ & $35(14.0)$ & \\
\hline Very severe >20 & 13315.3 & $32(8.9)$ & $21(8.4)$ & \\
\hline Stress & & & & 0.00 \\
\hline Normal (0-14) & $225(25.8)$ & $99(27.7)$ & $93(37.2)$ & \\
\hline Mild (15-18) & $189(21.7)$ & $66(18.4)$ & $69(27.6)$ & \\
\hline Moderate (19-25) & $177(20.3)$ & $66(18.4)$ & $32(12.8)$ & \\
\hline Severe (26-33) & $139(16.0)$ & $65(18.2)$ & $26(10.4)$ & \\
\hline $\begin{array}{l}\text { Very severe > 34 } \\
\text { Pittsburgh Sleep } \\
\text { Quality Index }\end{array}$ & $141(16.2)$ & $62(17.3)$ & $30(12.0)$ & \\
\hline $\begin{array}{l}\text { Good sleep } \\
\text { PSQI score < 5) }\end{array}$ & $243(39.4$ & $127(35$. & $118(47.4$ & \\
\hline $\begin{array}{l}\text { Average sleep } \\
\text { PSQI score 6-8) }\end{array}$ & $246(28.2$ & $103(28$. & $74(29.6$ & \\
\hline $\begin{array}{l}\text { Poor sleep (PSQI } \\
\text { score > 8) }\end{array}$ & $282(32.4$ & $128(35$. & $56(23.2$ & \\
\hline
\end{tabular}

Table no. 4. The mean scores of work-related burnout and their distribution of responses among frontline HCWs $(N=$ 1,479)

\begin{tabular}{|c|c|c|c|c|}
\hline Variables & $\begin{array}{c}\text { Physicians } \\
\text { N }=871\end{array}$ & $\begin{array}{l}\text { Nurses } \\
\mathbf{N}=358\end{array}$ & $\begin{array}{l}\text { Others } \\
N=\mathbf{2 5 0}\end{array}$ & Pvalue \\
\hline Work-related Burnout & $\begin{array}{l}\text { Mean } \pm \\
\text { SD }\end{array}$ & $\begin{array}{l}\text { Mean } \pm \\
\text { SD }\end{array}$ & $\begin{array}{l}\text { Mean } \pm \\
\text { SD }\end{array}$ & \\
\hline $\begin{array}{l}\text { 1. Are you exhausted in } \\
\text { morning? }\end{array}$ & $2.39 \pm 1.10$ & $2.37 \pm 1.13$ & $2.42 \pm 1.12$ & 0.817 \\
\hline $\begin{array}{l}\text { 2. Are you feeling that } \\
\text { every working tiring? }\end{array}$ & $1.91 \pm 1.21$ & $1.73 \pm 1.17$ & $1.78 \pm 1.20$ & 0.043 \\
\hline $\begin{array}{l}\text { 3. Do you have enough } \\
\text { energy for leisure time }\end{array}$ & $1.85 \pm 1.20$ & $1.63 \pm 1.19$ & $1.85 \pm 1.17$ & 0.014 \\
\hline $\begin{array}{l}\text { 4. Are you feeling that your } \\
\text { work is Emotionally } \\
\text { exhausting? }\end{array}$ & $1.81 \pm 1.21$ & $1.72 \pm 1.20$ & $1.72 \pm 1.18$ & 0.371 \\
\hline $\begin{array}{l}\text { 5. Are you feeling your } \\
\text { work frustrate you? }\end{array}$ & $1.63 \pm 1.17$ & $1.66 \pm 1.16$ & $1.44 \pm 1.18$ & 0.033 \\
\hline $\begin{array}{l}\text { 6. Are you feeling burnt } \\
\text { out (physical / } \\
\text { Mental exhaustion) of } \\
\text { your work? }\end{array}$ & $1.83 \pm 1.18$ & $1.67 \pm 1.16$ & $1.75 \pm 1.15$ & 0.090 \\
\hline \multicolumn{5}{|l|}{ Pandemic related burnout } \\
\hline $\begin{array}{l}\text { 1. Are you feeling is it hard } \\
\text { to work in the current } \\
\text { scenario? }\end{array}$ & $2.20 \pm 1.21$ & $2.25 \pm 1.28$ & $2.36 \pm 1.22$ & 0.202 \\
\hline $\begin{array}{l}\text { 2. Are you feeling worn end } \\
\text { of day }\end{array}$ & $2.72 \pm 1.10$ & $2.59 \pm 1.23$ & $2.72 \pm 1.14$ & 0.182 \\
\hline $\begin{array}{l}\text { 3. Are you feeling } \\
\text { depressed by current work? }\end{array}$ & $2.77 \pm 1.20$ & $2.64 \pm 1.33$ & $2.53 \pm 2.131$ & 0.017 \\
\hline $\begin{array}{l}\text { 4. Do you feel your patients } \\
\text { are tested? }\end{array}$ & $2.23 \pm 1.19$ & $1.92 \pm 1.16$ & $2.12 \pm 1.17$ & 0.001 \\
\hline $\begin{array}{l}\text { 5. Do you have fear to get } \\
\text { COVID-19 } \\
\text { Infection while working? }\end{array}$ & $1.59 \pm 1.18$ & $1.54 \pm 1.24$ & $1.69 \pm 1.22$ & 0.306 \\
\hline $\begin{array}{l}\text { 6. Are you feeling a fear of } \\
\text { family members get } \\
\text { COVID-19 from your } \\
\text { work? }\end{array}$ & $1.73 \pm 1.20$ & $1.66 \pm 1.34$ & $1.60 \pm 1.21$ & 0.271 \\
\hline
\end{tabular}

Table no. 5 presents the factor structure with principal component method of the DASS-21 among frontline HCWs sample. The Kaiser-Meyer-Olkin Measure was 0.840 and indicated that the data of the study were suitable for factor analysis. The factor analysis found out three factors with eigenvalue greater than one. Confirmatory factor analysis, which was conducted as a measure of internal construct validity, 


\section{PUBLIC HEALTH AND MANAGEMENT}

revealed satisfactory construct with very high CFI values. These factors were consistent with the original scale.

Table no. 5. Factor analyses of the DASS21 scale items using the varimax rotation among frontline HCWs surveyed $(\mathrm{N}=1,479)$ Rotated Component Matrix

\begin{tabular}{|l|l|c|c|}
\hline \multirow{2}{*}{ Rotated Component Matrix } & \multicolumn{3}{|c|}{ Component } \\
\cline { 2 - 4 } & $\mathbf{1}$ & $\mathbf{2}$ & $\mathbf{3}$ \\
\hline Depression & & & \\
\hline $\begin{array}{l}\text { D1.I could not seem experience of } \\
\text { positive feeling }\end{array}$ & 0.557 & & \\
\hline D.2.Couldn't seem to get going & 0.558 & & \\
\hline D.3.Nothing to look forward & 0.342 & & \\
\hline D.4.I felt Sad and Depress & 0.718 & & \\
\hline D.5.I felt lost interest & 0.708 & & \\
\hline D.6.I felt wasn't worth much person & 0.695 & & \\
\hline D.7.I felt life was not worthwhile & 0.797 & & \\
\hline Anxiety & & & \\
\hline A.1.Dryness of mouth & & 0.751 & \\
\hline A.2.Experienced breathing difficulty & & 0.763 & \\
\hline A.3.Feeling of shakiness & & 0.675 & \\
\hline A.4.Situations made me so anxious & & 0.547 & \\
\hline A.5.I had feeling of faintness & & 0.659 & \\
\hline A.6.Hands sweaty or physical exertion & & 0.650 & \\
\hline A.7.I felt scared without any reason & & 0.799 & \\
\hline Stress & & & \\
\hline S.1.I found myself getting upset & & & 0.544 \\
\hline S.2.Over-react to situations & & & 0.563 \\
\hline S.3.Difficult to relax & & & 0.508 \\
\hline S.4.Getting upset easily & & & 0.694 \\
\hline S.5.I felt nervous Energy & & & 0.801 \\
\hline S.6.I felt impatient when I was delayed & & & 0.753 \\
\hline S.7.I felt rather touchy & & & 0.666 \\
\hline Factor Eigen values & 4.527 & 1.462 & 1.323 \\
\hline Cronbach alfa & 1658 & 0.807 & 0.785 \\
\hline Variances(\%) & 11.833 & 9.322 \\
\hline
\end{tabular}

Method - principal component extraction, promax rotation; Cronbach Alf $=0.81$ Total Variances Explained $(\%)=74 ; \quad$ KMO value $=0.840 ; p<0.001$

As it can be seen from the table below, the multiple linear regression analysis revealed anxiety $(\mathrm{p}<0.001)$, stress $(\mathrm{p}<0.001)$, fear of COVID-19 and Burnout $(\mathrm{p}=0.008)$, depression $(\mathrm{p}=0.004)$, lack of sleeping- Pittsburgh Sleep Quality Index $(\mathrm{p}=0.014)$ and feeling exhausted $(\mathrm{p}=0.025)$ were associated with the quality of life during the COVID-19 pandemic after adjusting for the age and gender.

Table no. 6. The impact of depression, anxiety, stress, burnout and fear on the Quality life of frontline HCWs using Multiple Linear regression analysis

\begin{tabular}{|l|l|l|l|l|l|}
\hline $\begin{array}{l}\text { Independent } \\
\text { variables }\end{array}$ & $\mathbf{B}$ & $\begin{array}{l}\text { Std. } \\
\text { Error }\end{array}$ & $\boldsymbol{\beta}$ & $\mathbf{t}$ & $\mathbf{p}$ \\
\hline & & & & & \\
\hline Anxiety & 0.404 & 0.025 & 0.423 & 16.225 & 0.001 \\
\hline Stress & 0.443 & 0.027 & 0.423 & 16.225 & 0.001 \\
\hline Burnout & -0.047 & 0.018 & -0.069 & -2.638 & 0.008 \\
\hline $\begin{array}{l}\text { Fear of COVID- } \\
19\end{array}$ & 0.044 & 0.016 & 0.077 & 2.670 & 0.008 \\
\hline Depression & 0.096 & 0.033 & 0.074 & 2.864 & 0.004 \\
\hline $\begin{array}{l}\text { Lack of sleeping } \\
\text { Pittsburgh Sleep } \\
\text { Quality Index }\end{array}$ & -0.250 & 0.078 & -0.083 & -3.200 & 0.001 \\
\hline $\begin{array}{l}\text { Feeling mentally } \\
\text { exhausted }\end{array}$ & 0.221 & 0.099 & 0.064 & 2.237 & 0.025 \\
\hline
\end{tabular}

Table no. 7 indicates the statistical differences in scores among three different groups of HCWs. There were statistically significant differences between frontline three groups regarding depression $\quad(p>0.001)$, anxiety $(p=0.043)$, stress $\quad(p>0.001)$, burnout, PSQI subjective sleep quality $(p=0.005)$., PSQI sleep duration $(p=0.004)$, PSQI use of sleep medication $(\mathrm{p}=0.026)$, PSQI daytime dysfunction $(\mathrm{p}=0.003)$, WHOQOL general $(p>0.001)$., WHOQOL physical $(p>0.001)$, WHOQOL psychological $(p>0.001)$, WHOQOL social $(p>0.001)$ and WHOQOL environmental $(p>0.001)$ in terms of frontline professional status.
Table no. 7. Statistical differences in the scores for the scales, according to profession

\begin{tabular}{|l|l|l|l|c|}
\hline Variables & $\begin{array}{l}\text { Physician } \\
(\mathbf{n = 8 7 1}) \\
\text { Mean } \pm \text { SD }\end{array}$ & $\begin{array}{l}\text { Nurse } \\
(\mathbf{n = 3 5 8}) \\
\text { Mean } \pm \text { SD }\end{array}$ & $\begin{array}{l}\text { Other } \\
(\mathbf{n = 2 5 0}) \\
\text { Mean } \pm \text { SD }\end{array}$ & P value \\
\hline Age & $49.75 \pm 11.70$ & $41.37 \pm 10.30$ & $38.82 \pm 11.08$ & $\mathbf{0 . 0 1 5}$ \\
\hline DASS-21 Depression & $10.03 \pm 5.99$ & $8.44 \pm 5.71$ & $8.49 \pm 6.68$ & $\mathbf{0 . 0 0 1}$ \\
\hline DASS-21Anxiety & $10.88 \pm 8.10$ & $10.12 \pm 7.62$ & $9.30 \pm 7.32$ & $\mathbf{0 . 0 1 4}$ \\
\hline DASS-21 Stress & $10.98 \pm 783$ & $11.49 \pm 8.15$ & $9.17 \pm 7.28$ & $\mathbf{0 . 0 0 1}$ \\
\hline Fear of COVID-19 & $21.18 \pm 5.43$ & $21.75 \pm 5.510$ & $21.10 \pm 5.33$ & 0.202 \\
\hline Burnout & $24.74 \pm 5.65$ & $23.41 \pm 6.10$ & $23.58 \pm 5.93$ & $\mathbf{0 . 0 0 1}$ \\
\hline PSQI overall & $7.29 \pm 3.51$ & $7.67 \pm 3.45$ & $6.71 \pm 3.25$ & $\mathbf{0 . 0 0 4}$ \\
\hline $\begin{array}{l}\text { PSQI subjective sleep } \\
\text { quality }\end{array}$ & $0.71 \pm 0.83$ & $0.69 \pm 0.81$ & $0.51 \pm 0.71$ & $\mathbf{0 . 0 0 5}$ \\
\hline PSQI sleep duration & $1.43 \pm 0.84$ & $1.61 \pm 0.82$ & $1.41 \pm 0.85$ & $\mathbf{0 . 0 0 4}$ \\
\hline $\begin{array}{l}\text { PSQI habitual sleep } \\
\text { efficiency }\end{array}$ & $1.07 \pm 1.00$ & $1.00 \pm 0.96$ & $0.92 \pm 0.97$ & 0.137 \\
\hline $\begin{array}{l}\text { PSQI sleep } \\
\text { disturbances }\end{array}$ & $1.22 \pm 0.62$ & $1.19 \pm 0.64$ & $1.17 \pm 0.62$ & 0.628 \\
\hline $\begin{array}{l}\text { PSQI use of sleep } \\
\text { medication }\end{array}$ & $0.83 \pm 0.85$ & $0.90 \pm 0.89$ & $0.70 \pm 0.79$ & $\mathbf{0 . 0 2 6}$ \\
\hline $\begin{array}{l}\text { PSQI daytime } \\
\text { dysfunction }\end{array}$ & $1.69 \pm 1.54$ & $1.63 \pm 1.60$ & $1.28 \pm 1.38$ & $\mathbf{0 . 0 0 3}$ \\
\hline WHOQOL General & $6.75 \pm 1.85$ & $5.93 \pm 1.89$ & $6.26 \pm 3.03$ & $\mathbf{0 . 0 0 1}$ \\
\hline WHOQOL physical & $22.40 \pm 4.02$ & $20.50 \pm 4.23$ & $20.77 \pm 4.37$ & $\mathbf{0 . 0 0 1}$ \\
\hline $\begin{array}{l}\text { WHOQOL } \\
\text { psychological }\end{array}$ & $20.06 \pm 2.34$ & $17.89 \pm 4.61$ & $17.71 \pm 4.82$ & $\mathbf{0 . 0 0 1}$ \\
\hline WHOQOL social & $10.39 \pm 2.94$ & $9.09 \pm 2.45$ & $9.36 \pm 2.68$ & $\mathbf{0 . 0 0 1}$ \\
\hline $\begin{array}{l}\text { WHOQOL } \\
\text { environmental }\end{array}$ & $26.19 \pm 3.98$ & $24.03 \pm 4.67$ & $23.95 \pm 4.37$ & $\mathbf{0 . 0 0 1}$ \\
\hline & & & & \\
\hline
\end{tabular}

\section{DISCUSSIONS}

The aim of this study was to describe the impact of COVID-19, after one year of pandemic, on Turkish HCWs mental health in terms of depression, anxiety, stress, fear and burnout. The COVID-19 pandemic has become the biggest public health issue of the last 100 years, as well as the management and prevention of COVID-19 has become a major public health concern. In this study, the prevalence of depression, anxiety, stress and burnout among the HCWs were $77.4 \%, 60.8 \%, 72.4 \%$, and $76.4 \%$, respectively which were higher than in other studies. $(2,4,9,19,15,17)$

A previous study conducted in Istanbul found a high level of fatigue, stress, and fear among the Turkish population due to COVID-19.(2,4,9,19,16,17) The present study showed that depression, anxiety, and stress were all positively and significantly associated with the fear and burnout of COVID-19 and high among the frontline workers. These results are in line with previous reports from Italy $(2,6,13)$, Turkey $(4,9,15,20)$, China (7,14,17), India (5), Portugal (16), and Spain (19) confirming a substantial rate of mental health issues among frontline HCWs due to the current pandemic.

The findings of the study also suggested that fear of COVID-19 increases the likelihood of depression, anxiety, and stress: this is consistent with a recent study on Turkish population showing that the fear of COVID-19 was associated with psychological distress and burnout. $(5,16,19)$ The findings also found that depression, anxiety and stress have shown a high association with the fear of COVID-19 as it has been found in previous studies. $(2,4,9,19,16,17,26,27,28)$

The results of the study by Tengilimoğlu et al.(29) reported that the major cause of the depression, anxiety or stress among Turkish healthcare employees were from the fear of transmitting the COVID-19 virus to their relatives (86.9\%). These results are consistent with the current study (58\%). A substantial prevalence of burnout among healthcare workers in the frontline, particularly among young women and physicians, has been confirmed in line with previous studies from China (7), Italy $(22,13)$, India (5), Portugal (16), Spain (30) and Egypt.(31)

Limitations and strengths

Limitations may include the following: the design of the study was cross-sectional, which does not allow to determine any 


\section{PUBLIC HEALTH AND MANAGEMENT}

cause-effect relationship; we could not be able to retrieve information concerning psychological or psychiatric support received by HCWs. Conversely, the sample size was adequate and these data were collected during the current phase of pandemic, documenting the long- term effects (after one year from the outbreak) of COVID-19: most of surveys have been conducted in the first phase of the emergency. In fact, the strength of this study is the involvement of a very large sample of HCWs, all tested in the later phase of pandemic and suggesting on its potential long-term consequences.

\section{CONCLUSIONS}

The findings of this study show a significant impact of COVID-19 on mental health and quality of life among frontlineHCWs, which requires immediate action and support. This study revealed that there were statistically significant differences between the three groups (physicians, nurses and others) of HCWs regarding depression, anxiety, stress, burnout, quality of sleep and quality of life. This may suggest long-term differentiated programmes of support to be developed and delivered in the hospitals in order to address properly health needs of different professionals.

Ethics Committee Approval: The authors would like to thank the Istanbul Medipol University for their support and the Clinical Research Ethics Committee of Istanbul Medipol University, Institutional Review Board (Research Protocol and IRB\# E-10840098-772.02-1879).

Peer-review: Externally peer-reviewed

Contributors: $\mathrm{AB}$ contributed to conception, design, organized study, collected data, performed statistical analysis and wrote, and contributed to the to the interpretation of the data and writing, revised critically and approved final version of the manuscript.

DB and AV contributed to the literature review, interpretation of the data, and overseeing the final writing and editing of the manuscript, and approved final version of manuscript

Conflict of Interest: No conflict of interest was declared by the authors.

Financial Disclosure: The authors declared that this study has received no financial support.

\section{REFERENCES}

1. World Health Organization: Corona virus disease COVID2019 situation reports https://www.who.int/emergencies/diseases/novelcoronavirus-2019/situation-reports. Accessed 14 June 2021.

2. Trumello C, Bramanti SM, Ballarotto G, Candelori C, Cerniglia L, Cimino S, Crudele M, Lombardi L, Pignataro S, Viceconti ML, Babore A. Psychological Adjustment of Healthcare Workers in Italy during the COVID-19 Pandemic: Differences in Stress, Anxiety, Depression, Burnout, Secondary Trauma, and Compassion Satisfaction between Frontline and Non-Frontline Professionals. Int J Environ Res Public Health. 2020;12;17(22):8358.

3. Ornell F, Halpern SC, Kessler FHP, Narvaez JCM. The impact of the COVID-19 pandemic on the mental health of healthcare professionals. Cad Saude Publica. 2020;36(4), e00063520. https ://doi.org/10.1590/0102-311X0 0063520.

4. Elbay RY, Kurtulmuş A, Arpacioğlu S, Karadere E. Depression, anxiety, stress levels of physicians and associated factors in Covid-19 pandemics. Psychiatry Res. 2020;290:113130.

5. Khasne RW, Dhakulkar BS, Mahajan HC, Kulkarni AP. Burnout among Healthcare Workers during COVID-19 Pandemic in India: Results of a Questionnaire-based
Survey. Indian J Crit Care Med. 2020;24(8):664-671.

6. Di Tella M, Romeo A, Benfante A, Castelli L. Mental health of healthcare workers during the COVID-19 pandemic in Italy. J Eval Clin Pract. 2020;26(6):1583-7.

7. Zhou Y, Zhou Y, Song Y. Ren L, Ng CH, Xiang YT, et al. Tackling the mental health burden of frontline healthcare staff in the COVID-19 pandemic: China's experiences. Psychological Medicine; 2020, https ://doi.org/10.1017/S0033291720001622.

8. Hummel S, Oetjen N, Du J, Posenato E, Resende de Almeida RM, Losada R, Ribeiro O, Frisardi V, Hopper L, Rashid A, Nasser H, König A, Rudofsky G, Weidt S, Zafar A, Gronewold N, Mayer G, Schultz JH. Mental Health among Medical Professionals during the COVID-19 Pandemic in Eight European Countries: Cross-sectional Survey Study. J Med Internet Res. 2021;18;23(1):e24983.

9. Şahin MK, Aker S, Şahin G, Karabekiroğlu A. Prevalence of Depression, Anxiety, Distress and Insomnia and Related Factors in Healthcare Workers During COVID-19 Pandemic in Turkey. J Com Health. 2020;45:1168-1177.

10. Bener A, Morgul E, Atak M, Barışık CC. The impact of COVID-19 pandemic disease exposed with mental health in Turkey. Int J Clinical Psych Mental Health. 2020;8:1619.

11. Ahorsu D, Lin C, Imani V, Saffari M, Griffiths M, Pakpour A. The Fear of COVID-19 Scale: Development and initial validation. Int J Ment Health Addict; 2020 , https://doi.org/10.1007/s11469-020-00270-8.

12. Morgul E, Bener A, Atak M, Akyel S, Aktaş S, Bhugra D, Ventriglio A, Jordan TR.COVID-19 pandemic and psychological fatigue in Turkey. Int J Soc Psychiatry; 2020, 10:20764020941889. doi: $10.1177 / 0020764020941889$.

13. Rossi R, Socci V, Pacitti F, Di Lorenzo G, Di Marco A, Siracusano A, et al. (2020). Mental Health Outcomes Among Frontline and Second-Line Health Care Workers During the Coronavirus Disease 2019 (COVID-19) Pandemicin Italy. JAMA, 2020, Netw Open. 3(5):e2010185

14. Cai Q, Feng H, Huang J, Wang M, Wang Q, Lu X, et al. The mental health of frontline and non-frontline medical workers during the coronavirus disease 2019 (COVID-19) outbreak in China: A case-control study. J Affect Disord. 2020;275:210-5.

15. Öztürk Çopur E, Karasu F. The impact of the COVID-19 pandemic on the quality of life and depression, anxiety, and stress levels of individuals above the age of eighteen. Perspect Psychiatr Care; 2021. doi: 10.1111/ppc.12730.

16. Serrão C, Duarte, I, Castro L, Teixeira A. Burnout and Depression in Portuguese Healthcare Workers during the COVID-19 Pandemic-The Mediating Role of Psychological Resilience. Int J Environ. Res Pub Health. 2021;18:636

17. Lai J, Ma S, Wang Y, Cai Z, Hu J, Wei N, et al. Factors associated with mental health outcomes among health care workers exposed to coronavirus disease 2019. JAMA Network Open Journal. 2020;3(3);e203976.

18. Lovibond SH, Lovibond PF: Manual for the Depression Anxiety Stress Scales. 2. Edition. Sydney: Psychology Foundation; 1995.

19. Luceño-Moreno L, Talavera-Velasco B, García-Albuerne Y, Martín-García J. Symptoms of Posttraumatic Stress, Anxiety, Depression, Levels of Resilience and Burnout in Spanish Health Personnel during the COVID-19 Pandemic. Int. J Environ. Res. Public Health. 2020;17:5514

20. Satici B, Gocet-Tekin E, Deniz ME, Satici S. Adaptation of the Fear of COVID-19 Scale: Its association with 
psychological distress and life satisfaction in Turkey. Int $\mathbf{J}$ Ment Health Addict. 2020;8:1-9. doi: 10.1007/s11469-02000294-0.

21. Maslach C, Schaufeli WB, Leiter MP. Job burnout. Annu. Rev. Psychol. 2001;52:397-422.

22. Kristensen TS, Borritz M, Villadsen E, Christensen KB. The Copenhagen burnout inventory: a new tool for the assessment of burnout. Work Stress. 2005;19(3):192-207.

23. World Health Organization Quality of Life Group. The World Health Organization Quality of Life Assessment (WHOQOL-BREF): Introduction, Administration, Scoring and Generic Version of the Assessment; Programme on Mental Health: Geneva, Switzerland; 1996.

24. Skevington SM, Lotfy M, O'Connell KA, WHOQOL Group. The World Health Organization's WHOQOLBREF quality of life assessment: Psychometric properties and results of the international field trial. A report from the WHOQOL group. Qual. Life Res. 2004;13:299-310.

25. Buysse DJ, Reynolds 3rd CF, Monk TH, Berman SR, Kupfer DJ. The Pittsburgh Sleep Quality Index: a new instrument for psychiatric practice and research. Psychiatry Res. 1989;28:193-213.

26. Lapolla P, Mingoli A, Lee R. Deaths from COVID-19 in healthcare workers in Italy-What can we learn? Infection Control and Hospital Epidemiology; 2020, https ://doi.org/10.1017/ ice.2020.241.

27. Tan BY, Chew NW, Lee GK, Jing M, Goh Y, Yeo LL, et al. Psychological Impact of the COVID-19 Pandemic on Health Care Workers in Singapore. Ann Intern Med. 2020;173(4):317-20.

28. Nguyen LH, Drew DA, Graham MS, Joshi AD, Guo CG, $\mathrm{Ma} \mathrm{W}$, et al. Coronavirus Pandemic Epidemiology Consortium. Risk of COVID-19 among front-line healthcare workers and the general community: a prospective cohort study. Lancet Public Health. 2020;5(9):e475-83.

29. Tengilimoğlu $\mathrm{D}$, Zekioğlu A, Tosun N, Işık O, Tengilimoğlu O. Impacts of COVID-19 pandemic period on depression, anxiety and stress levels of the healthcare employees in Turkey. Leg Med (Tokyo). 2021;48:101811.

30. Torrente M, Sousa PAC, Sánchez-Ramos A, et al. To burnoutor not to burnout: a cross-sectional study in healthcare professionals in Spain during COVID-19 pandemic. BMJ Open. 2021;11:e044945. doi:10.1136/ bmjopen-2020-044945.

31. Elkholy H, Tawfik F, Ibrahim I, Salah El-Din W, Sabry M, Mohammed S, et al. Mental health of frontline healthcare workers exposed to COVID-19 in Egypt: a call for action. Int J Soc Psychiatry; 2020 doi: $10.1177 / 0020764020960192$. 